\title{
Accounting Management by International Standards
}

\author{
Jeno Beke \\ Institute of Business and Management, Faculty of Business and Economics, University of Pécs \\ 80 Rákóczi street, H-7622 Pécs, Hungary \\ Tel: 36-72-313-681Ｅ-mail: bekej@ktk.pte.hu
}

\begin{abstract}
This paper traces the benefits of international accounting standards - their contribution to harmonization and globalization by purposing and tasking for accounting management. Measuring in details their pros and cons effects on the division of labour, financial innovation, company transactions and cost of capital it could be author's recommendation for the business management inside and outside of one country's border. Especially the multinational companies whose subsidiaries had to report for some purposes (e.g. tax, local borrowing, benchmarking) using national accounting rules convert and consolidate their different framework for unified financial statement where they were listed. With the growth of international business transactions by private and public entities, organizations the need to coordinate different investment decisions has increased. A suitable accounting information system can help multinational enterprises accomplish their managerial functions on a global basis. In this viewpoint the adoption of international accounting standards can promote and support for the business management.
\end{abstract}

Keywords: Accounting management, International harmonization, Globalization, Standardization, Economics of accounting standards

\section{Introduction}

Accounting management is the practical application of management techniques to control and report on the financial resources of the business entities. This involves the analysis, planning, implementation, and control of programs designed to provide financial reporting for managerial decision making. It is covering the maintenance of the accounts, developing financial statements, cash flow and financial performance analysis. Since accounting applications do not have uniform security and reliability requirements, it is not possible to devise a single accounting protocol and set of security services that will meet all needs. Thus the goal of accounting management is to provide a set of tools that can be used to meet the requirements of each application. Accounting management requires that resource consumption be measured, rated, assigned, and communicated between appropriate parties. Especially the multinational companies spend enormous money for preparing and auditing their accounting reports according to the different national regulations. For these multinational companies the aspects of maximizing the profit is significantly more important than the consideration of national interest or the geographical position. Because of this there is a demand for creating such accounting systems which are evaluating the holder's economic results equally.

Meanwhile the interpretation and adoption of the financial information based on the different accounting rules, methods are also expensive for the users of these reports. Therefore an authentic and standardized international accounting system could form that business language, which would allow the comparison of the financial information of each country.

According to the business practice it is obvious that the usage of international accounting principles leads to a reduction of the information asymmetry between the owners and the managers. By this information asymmetry are growing the costs of equities and are less accurate the economical and financial forecasts. This requires the development and review of the national accounting rules, the separate validation of the tax and accounting regulation, the repeal of the subordinate role of accounting, issuing international standards with the help of practical and theoretical accounting experts.

Historically, standardization of the international accounting principles has tended to follow the integration of the markets served by the accounts. For example, the move to unified national accounting in the US in the early $20^{\text {th }}$ century followed the integration of the national economy. Similarly the present impetus for global accounting standards follows the accelerating integration of the world economy. Without the common accounting standards the cross-border portfolio and direct investment my be distorted, the cross-border monitoring of management by shareholders obstructed, and the cross-border contracting inhibited and the cost of these activities may be needlessly inflated by complex translation (Meeks and Swamm, 2009). 
To sum up, according to studies regarding the adoption of international financial accounting standards (IFRS), the companies that adopted IFRS needed to spend less time with earnings management and recognized loss more timely. These companies also experienced an improvement in their accounting quality. The adoption of IFRS also raised market liquidity and the value of the company. But we also have to add that these positive effects can be experienced mostly in those countries where the institutional background is appropriate. To be sure, arriving at accounting standards that promote a more faithful representation of economic reality is extremely challenging. Indeed, as some have argued, the economics of these transactions are often in the eye of the beholder (Zeff, 2006).

Accounting regulation in the European Union introduced from 2005 obligated economic entities listed and traded on stock markets to apply IFRS on consolidated financial statements exerted a decisive influence on the accounting globalization. The draft - accepted by the US Securities and Exchange Commission (SEC) - that enables the acceptance of financial statements created on the basis of IFRS without converting it according to US General Accepted Accounting Principles (GAAP) was a significant leap toward the convergence of IFRS and US GAAP. SEC is to examine the possibility for US economic entities to choose between US GAAP and IFRS for avoiding the necessity of revealing differences between the two systems and to conduct its comparison. Moreover on March 2007, SEC announced its intention to accept financial statements created in accordance with IFRS from January 1, 2009 beside the ones created according to US GAAP. Since in case such multinational companies like Daimler Chrysler owning more than 900 subsidiaries, operating on 5 continents in more than 60 counties, the published financial results according to international standards is 1.5 times of the one according to German accounting standards. If earning after taxation (EAT) - deducted actual tax burdens - according to US GAAP is taken as 100 percent, due to differences between national accounting standards, EAT would be $25 \%$ more in UK, 3\% less in France, 23\% less in Germany and 34\% less in Japan (Barth et al., 2007).

An analysis (Ormrod and Taylor, 2006) of non-economic entities among the 100 larges companies listed on London stock market was performed and published by the University of Liverpool, UK. This research created according to international accounting gave unique opportunities to retrieve comparable data. Financial performance of given period was examined and introduced according to international as well as British accounting standards indicating that in case of 50 out of 100 economic entities, conversion into IFRS would increase EAT by 39\%. Analysis was performed to find out which standards are reliable for that and turned out that only several of them caused the differences. In most of examined standards, results differed in a small proportion. Results were weighted on the bases of economic entities' size. Significant difference (24\%) was indicated by the review of goodwill. Financial investments accounted for the second important factor, resulting $13 \%$ changing. Applying to international accounting standards could decrease shareholders fund by $23 \%$. Converting to IFRS would indicate the most significant decrease in allowances (including pension), namely $26 \%$. Surprisingly most of the standards had minor deviations were indicated by dividend (3\%) and finite tax change $(1 \%)$. Allowances - especially pension - was expected to have significant effects, but it rather reflected the changes of British regulations instead of IFRS. Deviations of financial statement derived from different accounting system could hardly measure in case of such large companies like British Petrol.

One study (Bradshaw et al., 2008) characterizes of accounting amounts for companies that adopted IFRS to a matched sample of companies that did not, and found that the former evidenced less earnings management, more timely loss recognition, and more value relevance of accounting amount than did the latter. They found, that IFRS adopters had a higher frequency of large negative net income and generally exhibited higher accounting quality in the post-adoption period than they did in the pre-adoption period. The results suggested an improvement in accounting quality associated with using IFRS.

Another study (Sodestrom and Sun, 2007) found that first time mandatory adopters experience statistically significant increases in market liquidity and value after IFRS reporting becomes mandatory. The effects were found to range in magnitude from $3 \%$ to $6 \%$ for market liquidity and from $2 \%$ to $4 \%$ for company by market capitalization to the value of its assets by their replacement value.

\section{The financial statements' role in performance assessment of business management}

Financial statements, called "accounting statements" in Hungary reflects the results of management or the liability of management to enable making decisions like investment instruments should be maintained or should it be sold, or the assignment of management should be prolonged or should be replaced. Usually the total amount and availability of cash and cash equivalents are also requested and assessed since it determines the ability to fulfil obligations (transferring for suppliers, interests and paying out dividend for shareholders). Users of financial statements could even better assess the total amount of cash and cash equivalents if the statement 
focuses on the financial situation, performance of the business. Financial situation of given economic entity is influenced by the possessed economic resources, financial structure of the entity, its liquidity and ability to adopt environmental changes. Preceding data on possessed economic resources and its changes in the past may be useful to create cash and cash equivalents forecasts while preceding data on financial structure could be used for set up loan forecasts and to determine how future revenues will be divided among shareholders. Analyzing accounting information may also be used to determine how successful the business will be in acquiring additional finances. Forecasts based on former rate of liquidity and dispensability may indicate whether the entity will be able to fulfil its due obligations. Data on the performance of business, especially on its profit are required to forecast the future changes of economic resources which the business is likely to possess, thus data on changes of performance is relevant. From financial forecasts, trend-extrapolations the following conclusions may be drawn: whether the given business could raise cash-flow on the basis of existing resources or not; how successfully it could use additional financial resources. Business' ability of raising cash and cash equivalents and cash flow may be derived from all these information. Several means of funds could be determined while creating forecasts of financial situation of given business, like financial resources, working capital, liquid or financial instruments. Information on financial situation primarily indicated in balance sheets while information on performance is indicated in profit and loss statements. Some components of financial statements are connected to each other since they are derived from the same transactions or event. Despite the fact that all of the statements provide different information, presumably none of them serves only a single purpose or contains answers to all requested questions. Profit and loss statement, statement of cash flow together with a balance sheet could provide an overview of economic entity's performance.

\section{Role of international accounting standards in the division of labour}

Even the work of Adam Smith concerning division of work demonstrate the significant change that leads from economic entities managed by its owner through divided leadership between shareholder till hired management. Hired management of limited partnership may provide further options for maximize risk management and financing such projects that exceed the possibilities which are available for economic entities managed by its owner. In addition monitoring fund assessment and investment may be challenging without hired experts. Informational asymmetry may occur concerning asset valuation namely external shareholders are usually less informed of financial investments than hired managers which also may cause motivational anxiety. As Adam Smith (1776: 89) has written "Management of such partnerships rather handles shareholders' investments than its own thus the same caution could not be expected that lead to lavishing of funds..."

The study of Gwilliam et al. (2005) describes the role of international accounting standards in division of labour, but first of all regarding in absence of its adoption: In 1980, Lloyd, one of the largest retail chains in the UK created and published its financial statement without taking into consideration the accounting and audit regulations since the latter one was not in force. Defaults of information flow between branch offices and management could be traced back to the lack of modern and uniformed accounting standards. Different sales values and funds were indicated by the branch offices and by the headquarters due to differing accounting principles and methods and self-interests.

Concerning decisions on fund assessment and investments Smith (1996) gave the following examples for the misuse of accounting standards: The Coloroll share company operation in the UK, grew to 10 times of original company within 4 years thanks to acquisitions but kept low rate of (fictive) profit by using accounting tricks, "creating reorganizing reserves". Next year its capital has degraded and bankrupted. The Accounting Standard Board (ASB) in UK has created and published unified principles and accounting methods to avoid such misunderstandings, differences and failures between economic entities participating in the division of labour. Their aim was to eliminate bankruptcy of such large company like the British Coloroll or the American WorldCom. The board consisting of accounting researchers, experts, auditors aimed to create such standards like restrains management from misinforming shareholders concerning the profit achieved by company or the amount of dividend. In addition Botsari and Meeks (2008) have created such accounting methods that restrain management from altering former performance, results. Similar case has been published recently in Hungary: the First Hungarian Natural Gas and Energy Trading and Service Provider Ltd tried to alternate its profit by self-revision to "achieve" loss. Shleifer and Vishny (2003) - in their study - introduced methods that may prevent company management from misinforming shareholders by motivating them to apply accounting standards especially in the statements of their performance and funds.

Adoption of IFRS may lead to less time being spent trying to be in line with all the strict rules and regulations that come with the national rule-based accounting. Western European and American multinational corporations have been often outsourcing their accounting tasks to lower cost countries. If a globally accepted financial 
reporting standard was available, it would be even more likely that companies would contract out their accounting tasks to lower cost countries. Currently, the management of companies from developed countries might be concerned that they do not find the necessary accounting expertise in developing countries. With the adoption of the worldwide accounting standards, companies could centralize accounting training and could easily set up centralized financial support centres. The number of shared (financial and administrative) service centres could increase considerably. This would benefit the multinational corporations and create a significant number of new jobs in developing countries. With globalization under way, accounting professionals could easily reallocate (especially in the European Union where there are no country borders anymore) to other countries as accounting and financial statement would have a common language. The companies in countries like India, Mexico or even Hungary, have more and more duties taken over from the firms of developed countries and from other organizations. The market is developing, because there is a demand and also supply and the unionisation take over simpler and more transparent.

\section{International accounting standards and financial innovation}

Statement that standardization has a leading role in innovation is proven in numerous studies e.g. Temple (2005). According to data provided in above mentioned study, $50 \%$ of the interviewed person conceived that accounting standards promote innovation. The other $50 \%$ of them stated that standards restrain innovation. This involves that standards may promote or restrain innovation as well. This could question mark the role of standards in innovation. As mentioned above and argued by Smith, division of labour promote innovation. New markets could be achieved by using standards thus new markets entries and products may give a significant boost to innovation - as argued by Whittington (2008).

Using widely accepted standards for innovative products could also result in better sales figures. Without these standards, low-quality products and remaining stocks could not be relocated, thus innovation would lose its economy-boosting effect. In addition new standards expand the scale of innovative products, market entries thus without new standards, innovative products could be hardly obtained. Loan contracts may also provide us a perfect example for the role of standards in financial innovation. International accounting information has already took a significant part of such contract, but for now adopting these information for performance assessment become more and more complex. Fluctuation of interest rate is highly influenced by innovation (Chatterjee, 2006). This involves that higher risk advantage could be achieved through lower interest rate and the lack of negotiations before signing contracts. On the other hand lenders are compensated through exercising extra premium in the interest rate. With such a warranty, lower interest rate could be set, thus both lender and debtor could meet beneficial offer. Even so in some case - e.g. mentioned in their study of Fearnley and Sunder (2007) - terms indicated in the contract were defaulted due to false determination of profit, lowered loan risks "accounting tricks" or due to defaulted payment of instalment. Thus uniformed contract and standardized international accounting methods should be introduced.

In many countries the growth of the financial leasing proves that leasing is like a financial innovation that obtained a long-lasting position in the economic life. The success of leasing could be explained by the arising needs of financial capacity in the economy, and not with the temporary favourable environmental conditions. Alongside the clients in the frame of financial innovation there is an increasing demand for services and goods for handling wealth, and for that, to have a higher benefit in the case of unfavourable financial conditions.

\section{The effects of international accounting standards on the transaction costs}

Financial markets can not be misled by accounting tricks for good. Despite the fact that information concerning market prices could not be published by using international accounting standards, it remains essential to assess stock prices. If an economic entity has a semi-massive effect in a country stock prices will react to published information nevertheless the principles or methods were used in financial statements.

Literature (e.g. Easton, 2006) lists many events proves that in many cases market participant did not reacted to changes of reports (performance, profit and loss statements) mainly due to shift in used standards. For example: an economic entity changed its amortization method to achieve higher profit rate. Since market participant had enough information that the increase in profit was due to amortizing assets, stock price of given entity has not risen.

Similar effects could be experienced in case of mergers and acquisitions in the USA (Daske et al., 2008) since market participant were not touched by the fact, that increased profit was due to amortizing assets not performed before merge. Consequently standards should be used to eliminate manipulations, extra work caused by the alternations and unnecessary costs. 
Another part of transaction costs are affected by international accounting standards, e.g.: costs connected to signing a loan contract or "so-called contract". Accounting data may limit contracting parties' freedom getting the relevant information needed for being able to represent their interest, e.g. information provided by loan contract on debtor's engagement or limitation of the liability management.

Invoice of business tax may be mentioned as a theoretical example for "so-called contracts" since EBT (earnings before taxation) and EAT may differ significantly as later one is to be modified by accounting standards, rates and indexes. It is especially typical to the third sector where income is strongly affected by international accounting standards.

Epstein (2009) highlights the cost-saving effect of international accounting principles in connection with contracts since without their standards, lender would be forced into contracts that may push them toward bankruptcy.

Both lender and debtor prefer accurately defined obligations and demands that may be detailed by international accounting standards. Efficiency of loan contracts may be increased by using more transparent, comprehensible and comparable reports based on international accounting standards since misconceived reports may lead to losses decreasing assets. These losses could be derived from false assessment of assets, obligations, consolidated profit or net assets. Since information on which reports are based on these standards may not be compensated by other resources, it motivates market participants to rely on such reports and decrease risk of investments by that.

Applying international accounting standards may also decrease the costs of data processing systems since it supersedes to store and process differed data. The more standardized the financial data base is, the higher the benefit gained. Unified international accounting principles may enhance cross-border investments, increasing their benefits. Since accounting standards may enhance the ability of forecasting profit rate, it could act as potential opportunity for investors.

Due to experts' opinions and impact studies, profit increasing effect of international accounting standards through cost-saving (transaction costs, costs of management) is proven.

\section{International accounting standards decrease costs of capital}

Practically speaking accounting is an instrument to project economic transactions and assess their performance. Particularly the later could be a remarkable tool for financial market participants when indicating accurate data on the financial situation, performance, mobility of resources, obligations due of examined business. Domestic investors prefer domestic business since reports are created according to well-known international accounting standards and can be interpreted easily. On the other hand foreign investors prefer reports created on the basis of international standards rather than domestic standards. Costs of foreign investments could also be reduced if invested to the optimal opportunity where cost of managing active investments could be reduced to minimal level while maximizing profit.

About 1000 foreign companies registered at SEC, converted their accounting reports from their national accounting rules according to US GAAP and are listed and traded on the stock market of USA. But only some of them have adequate methods (instrument of governance ability to classify and account activities, ability to initiate claims) in order to defend the interests of investors. Therefore they are exposing their voluntary-ness to risk of being sued on the basis of insufficient investment-protection which blocks the further advantages of using US GAAP. Thus risk of exchanging stock may also increase the cost of capital since it is connected to the risk level of investment (decreasing risk factors results in the decrease of transaction cost emerging during investment). Risk may derive from the reliability of the accounting statements of business' financial position its performance. The cost-saving effects (through decreasing risk level of assets) of a reliable and true financial statement is proven by numerous studies (including Easley,D.- Hara.M. , 2004, and Ball et al., 2006, researches), since reliability of accounting data effects on the price of assets. The above mentioned studies have pointed out, that only a management providing exact and reliable information to shareholders could take effect on the cost of capital. Accordingly international accounting standards and unified methods could assist shareholders since unreliable reports mean a possible risk-factor. This accounting model based on the principles of historical costs for invested vehicles distort it's the real value if it is too late defined as realizable income from cash flow applying financial resources. The invested vehicles receive criticism nowadays that may lead to the review of financial resources' evaluation. Necessity for re-evaluating applied international standards of the financial instruments was suggested by experts due to present sub-primed mortgage and economic crisis.

For examining accounting standards from a different point of view confirmed the fact, that unreliable information used in reports may further increase cost of capital. The complexity and misconception of financial 
statements may cause higher risk factors resulting in longer rate of return and higher costs of capital. Without doubt it may be concluded that accounting risk could be lowered with the use of reliable and true international accounting standards.

If shareholders blindly trust in published reports may become a risk-factor as well. It also depends on how shareholders trust in the regulations over financial statements (e.g.: SEC in the USA), technical background and knowledge of auditors to enforce international accounting standards. Considering all factors mentioned above, it could be declared that increasing reliability and better interpretability of information provided in financial statements could decrease investors' cost of capital. Beside direct risk-factors, indirect risk-factors do also have effects on investors' cost of capital.

Reporting according to IFRS provide much better access to world capital markets, which reduces the cost of capital. Investors cannot easily interpret the given countries' national financial reports. They are very reluctant to invest in companies without clear financials. It is high risk to invest in companies without easily accessible, clear financial reports. Investors expect higher returns from these companies, thus the cost of debt is higher for companies not preparing IFRS reports. IFRS put the financial statements in a simple and understandable form for investors and other parties interested in the firm. IFRS financial statements could have a positive effect on companies' credit ratings thus the cost of borrowing may be reduced. IFRS are also widely accepted as the financial statements framework for companies who would like to get admitted to any of the world's stock exchanges. Since worldwide adoption of IFRS would create a common language for accounting, new capital markets would be opened to companies who have been reporting only in accordance with their national standards. One can easily say that companies have the opportunity to prepare their statements according to IFRS. However, small and middle size companies do not have enough funds and manpower to complete their financials both according to the national standards required by the law and according to IFRS, which would be desirable to enter the international capital markets.

\section{Conclusion}

Standardization of financial accounting has tended to follow the integration of the markets served by the accounts. The present impetus for global accounting standards follows the accelerating integration of the word economy. The global accounting standards would enable the world's stock markets to become more closely integrated. The more closely world's stock markets approach a single market, therefore, the lower should be the transaction costs for investors and the cost of capital for firms in that market. The differences in international reporting practice prior to IFRS constituted a palpable barrier to efficient international investment, monitoring and contracting. And the literature suggest that being confined to small segmented capital markets imposes a substantially larger cost of capital on firms and transaction costs on investors, which would inhibit much worthwhile investment. Although we do not have all elements for the cost-benefit calculation, the evidence points to substantial net gains for smaller economies which have joined to the IFRS regime. There is certainly empirical research evidence to support the notion that uniform financial reporting standards will increase market liquidity, decrease transaction costs for investors, lower cost of capital, and facilitate international capital formation and flow. And there is a sufficient basis to endorse IFRS and begin the challenging task of educating users, auditors, and regulators. Educators and practicing accountants alike have significant roles to play in this exciting future.

International accounting standards create more transparency on the financial market. This provides investors more accurate information on company profiles. This way, even small investors (and not only professionals) will be able to get the information needed for their investment choices, thus they will be able to better compete on the market. More transparency will result in more international transactions that will have reduced costs because of the clear information provided by companies' reports. In case of consolidated accounts (when the company has foreign subsidiaries) bookkeeping will be facilitated and will also result in reduced transaction costs. No more adjustments will be needed in order to make financial reports of companies internationally comparable. Reduced costs will also result in more cross-listings and cross-border investments. International accounting standards also have a good effect on the division of labour. These standards and thus the less transaction costs will enable companies to be able to trade easier between each other. This will let them specialise in the field of their strengths and rather rely on suppliers that are also specialists in another field of their own than trying to produce the same product in-house, which will create a division of labour on the market. Accounting standards also provide information on company disclosure. Better transparency, by providing more information, and providing the accurate and understandable information will reduce the risk perceived by investors. The risk in question is the accounting risk that comes from the difficulties in understanding the accounting principles and standards applied by the firm, and also the inability of investors to process the information provided. By reduced risk 
investors will get lower returns from their investments that will result in lower cost of capital as well. Companies that are using IFRS face less earning management, more earnings and more value relevance of earnings. This can be due to the easier flow of capital, the less costs attributable to the difficulties of adjusting the reports of companies from different accounting systems. Due to the decreasing costs of processing the information provided in financial statements the efficiency of stock markets will increase which will result in greater prices of stocks and thus greater capital income for enterprises. These all will provide space for more innovation on the financial markets because they could become more integrated, and more and new international transactions could be created. Due to accounting standards, the international flow of capital will be easier.

International accounting standards are also becoming more popular and tend towards integration as the global economy. The global standards have many benefits that are supported by many factors. However, there exist also some restraining factors. Due to the globalisation of the markets, international investors need access to financial information of companies that is easier by harmonized accounting standards. Many economic choices are done when investors realise their activities. These economic factors mostly favour international harmonization. Clear information is needed in order to facilitate investments in all sectors.

It seems to be apparent that the appropriate international accounting standards contribute to the division of labour, to financial innovation and to the reduction of the transactional costs, the cost of capital and even to the increase of the enterprises' earnings. The first argument for the harmonization of accounting standards is the existence of the multinational companies, who invest enormous efforts into the preparation of their financial statements in order to comply with the national standards. For these companies life would be much easier if the same rules would apply to their subsidiaries all around the world. On the other hand this would be profitable for the investors as well, as they could compare the enterprises' results without difficulties, which would spare both money and other resources for them. This would also lead to the reduction of the information asymmetry between managers and investors. The information asymmetry is a costly thing which can be blamed for the increase of the equity's cost and the inaccuracy of the economical and the financial forecasts. So the aim of the international accounting standards is that similar transactions are treated the same way all around the globe which enables the creation of unified financial statements.

\section{References}

Adam Smith. (1776). The Wealth of Nations. London.

Ball, R., Robin, A., and Sadka, G. (2006). Are timeliness an conservatism due to debt or equity markets?. Manuscript, University of Chicago.

Barth,E., Landsmann,R., and Lang, H. (2007). International Accounting Standards and Accounting Quality. Research Paper, Stanford University, USA.

Botsari, A., and Meeks, G. (2008). Do acquirers manage earnings prior to share for share bid? Journal of Business Finance and Accounting, 35, 633-670.

Bradshaw, M., Mark, T., and Miller, G. (2008). Will Harmonizing Accounting Standards Really Harmonize Accounting? Journal of Accounting, Auditing and Finance, 6, 148-161.

Chatterjee, R. (2006). Performance pricing and covenants in debt contracts in the UK. Working Paper, University of Cambridge, 7.

Daske,H., Hail. L., Leuz, C., and Verdi, R. (2008). Mandatory IFRS on the economic Consequences. Working Paper, University of Chicago.

Easley,D., and Hara,.M. (2004). Information and the Cost of Capital. The Journal of Finance, 59, 59-71.

Easton, P. (2006). Use of forecasts of earnings to estimate and compare cost of capital across regimes. Journal of Business Finance \& Accounting Research. 23/ 2, 74-89.

Epstein, B., J. (2009). The Economic Effects of IFRS Adoption. The CPA Journal, 3, 26-31.

Fearnley, S., and Sunder, S. (2007). Competition required to reduce standards complexities. Financial Times, 17, 19.

Gwilliam, D., Macve, R., and Meeks, G. (2005). The costs and benefits of capital do legal institutions and securities regulation matter? Journal of Accounting Research, 44, 485-531.

Meeks, G., and Swamm, P. (2009). Accounting standards and the economics of standards. Accounting and Business Research, 39, 191-210. 
Ormrod, P., and Taylor, P. (2006). A study of the impact of IFRS adoption has looked beyond the early adopters for evidence. Journal of Accounting, 12, 82-84.

Schleifer, A., and Vishny, R. (2003). Stock market driven acquisitions. Journal of Financial Economics, 70, 295-311.

Smith, T. (1996). Accounting for Growth, $2^{\text {nd }}$ edition, London.

Sodestrom, N., and Sun, K. (1996). IFRS Adoption and Accounting Quality. European Accounting Review, 16, 675-702.

Temple, P. (2005). The Empirical Economics of Standards. DTI Economics Paper, 12, London.

Whittington, G. (2008). Harmonisation or discord? The critical role of the IASB conceptual framework review. Journal of Accounting and Public Policy, 27, 495-502.

Zeff, R. (2006). Political lobbying on accounting standards - national and international experience, In.: Nobes, C. and Parker, R.: Comparative International Accounting, $9^{\text {th }}$ edition, London. 